\title{
Use of piezosurgery and an anti-inflammatory medication to prevent postoperative edema: Objective assessment using lateral nasal radiography
}

\author{
Ameliyat sonrası ödemi önlemek için piezocerrahi ve antiinflamatuvar ilaç kullanımı: \\ Lateral nazal radyografi kullanarak objektif değgerlendirme
}

Ali Seyed Resuli (i)

Department of Otolaryngology, Istanbul Yeni Yüzyll University, Istanbul, Turkey

\begin{abstract}
Objectives: This study aims to investigate if morbidities after rhinoplasty, including edema, can be prevented if piezosurgery is employed and anti-inflammatory agents are prescribed.

Patients and Methods: This prospective study, conducted between December 2019 and March 2020, included 96 patients ( 57 males, 39 females; mean age 25.6 years; range, 18 to 35 years) who underwent open rhinoplasty. Patients were randomly divided into four groups: group 1 underwent conventional osteotomy, group 2 was performed conventional osteotomy with prescription of an anti-inflammatory agent, group 3 was performed piezosurgery, and group 4 was performed piezosurgery with prescription of an antiinflammatory agent. Postoperative edema was evaluated via lateral nasal radiography on days one, three, and seven.

Results: Nasal edema scores were significantly lower when piezoelectric rather than conventional osteotomy was performed. An anti-inflammatory agent significantly reduced edema one day after conventional osteotomy but the agent had no effect at any other time after either type of surgery.

Conclusion: Piezosurgery effectively prevents edema after rhinoplastic osteotomy. Single dose anti-inflammatory therapy was not effective later than one day after conventional surgery and not at all after piezosurgery. Lateral nasal radiography is accurate, practical, easily accessible, inexpensive, and objective. Keywords: Edema, lateral nasal radiography, osteotomy, piezosurgery, rhinoplasty.
\end{abstract}

$\ddot{O Z Z}$

Amaç: $\mathrm{Bu}$ çalışmada rinoplasti sonrasında piezocerrahi uygulanır ve antiinflamatuvar ajanlar reçetelenirse ödem dahil morbiditelerin önlenip önlenemeyeceği araştırıldı.

Hastalar ve Yöntemler: Aralık 2019 - Mart 2019 tarihleri arasında gerçekleştirilen bu prospektif çalışmaya açık rinoplasti geçirdi 96 hasta (57 erkek, 39 kadın; ort. yaş 25.6 yıl; dağılım, 18-35 yıl) dahil edildi. Hastalar randomize şekilde dört gruba ayrıldı: grup 1 konvansiyonel osteotomi geçirdi, grup 2'ye bir antiinflamatuvar ajan reçetelemesiyle konvansiyonel osteotomi uygulandı, grup 3'e piezocerrahi uygulandı ve grup 4'e bir antiinflamatuvar ajan reçetelemesiyle piezocerrahi uyguland. Ameliyat sonrası ödem bir, üç ve yedinci günlerde lateral nazal radyografi yoluyla değerlendirildi.

Bulgular: Nazal ödem skorları konvansiyonel değil, piezoelektrik osteotomi uygulandığında anlamlı şekilde daha düşüktü. Antiinflamatuvar ajan konvansiyonel osteotomiden bir gün sonra ödemi anlamlı şekilde azalttı fakat ajanın her iki tip cerrahiden sonra diğer hiçbir zamanda etkisi olmadı.

Sonuç: Piezocerrahi, rinoplastik osteotomiden sonra ödemi etkili şekilde önler. Tek doz antiinflamatuvar terapi konvansiyonel cerrahi sonrası bir günden sonra etkili değilken piezocerrahi sonrası hiç etkili değildi. Lateral nazal radyografi doğru, pratik, kolay erişilebilir, masrafsız ve objektiftir.

Anahtar sözcükler: Ödem, lateral nazal radyografi, osteotomi, piezocerrahi, rinoplasti.

Received: March 09, 2020 Accepted: March 28, 2020 Published online: June 11, 2020

Correspondence: Ali Seyed Resuli, MD. Bahat Hastanesi Kulak Burun Boğaz Bölümü, 34270 Sultangazi, İstanbul, Türkiye. e-mail: a.s.resul@hotmail.com 
The most important stage of rhinoplasty is the correction of nasal bone deformities. The bony roof and lateral walls of the nose are often managed mechanically using osteotomes, chisels, rasps, and saws. The most significant complications of rhinoplasty are persistent edema and ecchymosis caused by soft tissue damage. Methods that minimize undesired fractures have been developed. Piezosurgery is one such recent method $;^{[1,2]}$ in it, ultrasonic vibrations are used to cut nasal bones with high precision (Mectron Medical Technology, Carasco, Italy). Osteotomies performed with piezoelectric devices are safer and more sensitive than conventional osteotomies, and are associated with less osteonecrosis. ${ }^{[3,4]}$ Jean and Marie Curie, in 1880, were the first to discover the piezoelectric effect on mineralized tissues; an electric current created ultrasonic oscillations. A piezoelectric device generates linear microvibrations $60-210 \mu \mathrm{m}$ in amplitude at $25-30 \mathrm{kHz}$. An irrigation system prevents tissue overheating. The device cuts mineralized tissues only, not soft tissues such as nerves and vessels. ${ }^{[5]}$ The first rhinoplastic piezoelectric device was developed by Robiony et al. ${ }^{[6]}$ Osteotomy soft tissue complications including edema, ecchymosis, and postoperative bleeding are minimized using this new method. Mirza et al. ${ }^{[3]}$ compared the postoperative outcomes of patients undergoing nasal hump and lateral osteotomies employing piezosurgery and other techniques. Compared to a conventional osteotome, the piezoelectric device reduced eyelid edema, ecchymosis, and bleeding in all studies except one; in two studies, postoperative pain was reduced by piezosurgery. However, piezosurgery requires significantly longer operation times. In addition, it is expensive and the surgeon must take care to prevent skin burns when holding the handpiece. ${ }^{[7]}$

The four-grade visual scale of Kara and Gökalan, ${ }^{[8]}$ the modified Yücel version, ${ }^{[9]}$ and the three-grade scoring system of Tirelli et al. ${ }^{[10]}$ have been used to compare post-rhinoplasty edema after piezoelectric and conventional surgeries. In the Kara and Gökalan ${ }^{[8]}$ system, eyelid edema is graded 0 (absent), 1 (minimal), 2 (extending to the iris), 3 (covering the iris), and 4 (massive; eyelid closed). In the system of Tirelli et al., ${ }^{[10]}$ grade 0 reflects the absence of edema and ecchymosis, grade 1 is low-level edema and ecchymosis limited to the zygomatic region, and grade 2 is severe edema and "raccoon eyes." Both systems are subjective. No objective system has yet been used to assess edema developing after rhinoplasty. Therefore, in this study, we aimed to investigate if morbidities after rhinoplasty, including edema, can be prevented if piezosurgery is employed and anti-inflammatory agents are prescribed.

\section{PATIENTS AND METHODS}

This prospective study, conducted between December 2019 and March 2020, included 96 patients (57 males, 39 females; mean age 25.6 years; range, 18 to 35 years) who underwent open septorhinoplasty performed by a single surgeon in Istanbul Yeni Yuzyil University and Bahat Hospital Otolaryngology and Throat Clinics. The study protocol was approved by the Yeni Yüzyıl University Ethics Committee (approval no. 19.12.2019/55). A written informed consent was obtained from each patient. The study was conducted in accordance with the principles of the Declaration of Helsinki. The patients were randomly divided into four groups: group $1 \quad(n=22)$ underwent conventional osteotomy, group $2 \quad(\mathrm{n}=23)$ underwent conventional osteotomy and received an anti-inflammatory agent, group $3(\mathrm{n}=25)$ underwent piezosurgery, and group 4 $(n=26)$ underwent piezosurgery and received an antiinflammatory agent. The inclusion criteria were a nasal deformity with or without nasal obstruction, a nasal trauma, and age over 18 years. Patients lacking nasal bone deformities who were thus not scheduled for nasal hump reduction or lateral osteotomy were excluded, as were those who had undergone prior nasal surgery, had acute or chronic sinusitis or nasal polyps, used anticoagulant drugs, or exhibited bleeding diathesis associated with chronic disease.

All patients underwent open rhinoplasty under general anesthesia; all operations commenced with a mid-columellar V-shaped incision. A columellar flap was elevated in the subcutaneous plane. Caudal subperichondral dissection in the subperiosteal plane continued until the fronto-nasal connection was attained; this exposed the nasal skeleton. If a septal deviation was apparent, both sides of the septal mucopericondria were elevated, septoplasty was performed, and cartilage grafts were harvested. The nasal dorsal hump was resected using a piezoelectric device (Guilin Woodpecker Medical Instrument Co Ltd. Guilin, Guangxi, China) (Figure 1a) or a conventional osteotome (Bahadır Tibbi Aletler AŞ., Samsun, Turkey) (Figure 1d). Tip plasty was performed if necessary after the medial and lateral crura were exposed. Immediately thereafter, median oblique and lateral osteotomies were performed using a piezoelectric device (Figure 1b, c) or a conventional osteotome (Figure 1e, f). Small-vessel bleeding was prevented by icing and buffering. All patients wore intranasal splint tampons for three days and external plastic nasal splints for seven days. To reduce edema and ecchymosis, ice packs were applied for $45 \mathrm{~min}$ of every hour for 12 hours. Dexamethasone $8 \mathrm{mg} / \mathrm{kg}$ and ranitidine $25 \mathrm{mg} / \mathrm{mL}$ were given intravenously $30 \mathrm{~min}$ before surgery to patients in groups 2 and 4 . 

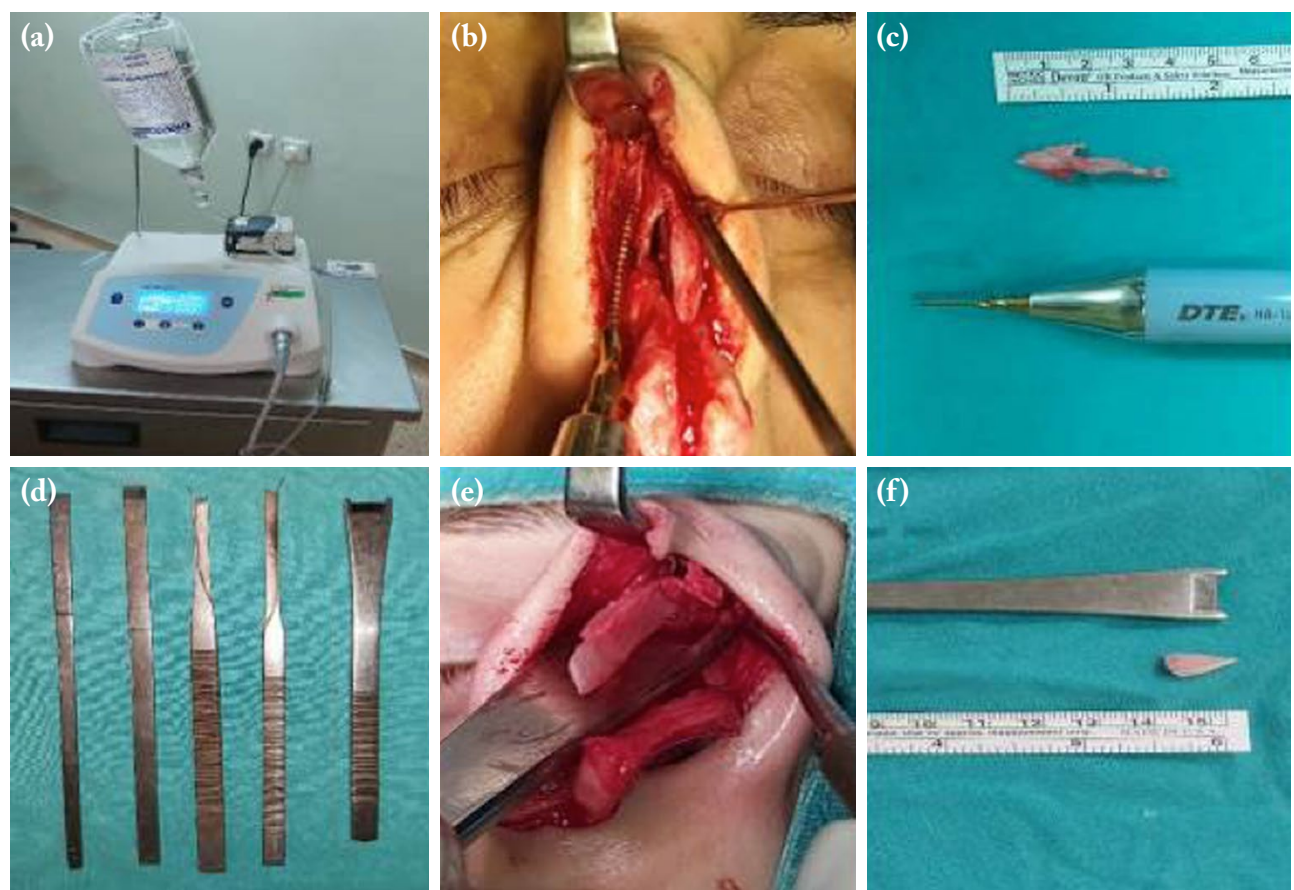

Figure 1. (a) Piezoelectric device. (b) Osteotomy was performed using a piezoelectric device. (c) Resected hump with piezoelectric. (d) Conventional osteotomes. (e) Osteotomy was performed using a conventional osteotome. (f) Resected hump with conventional osteotome.

The edema score was the distance between the periosteum and dermis as measured from the midpoints of the rhinion and nasion evident on radiographs (Figure 2).
Possibly pregnant female patients did not undergo radiography. Each patient was laid prone on a table. The cassettes and detectors were small, and the radiographic field was not compromised. The tube-cassette distance
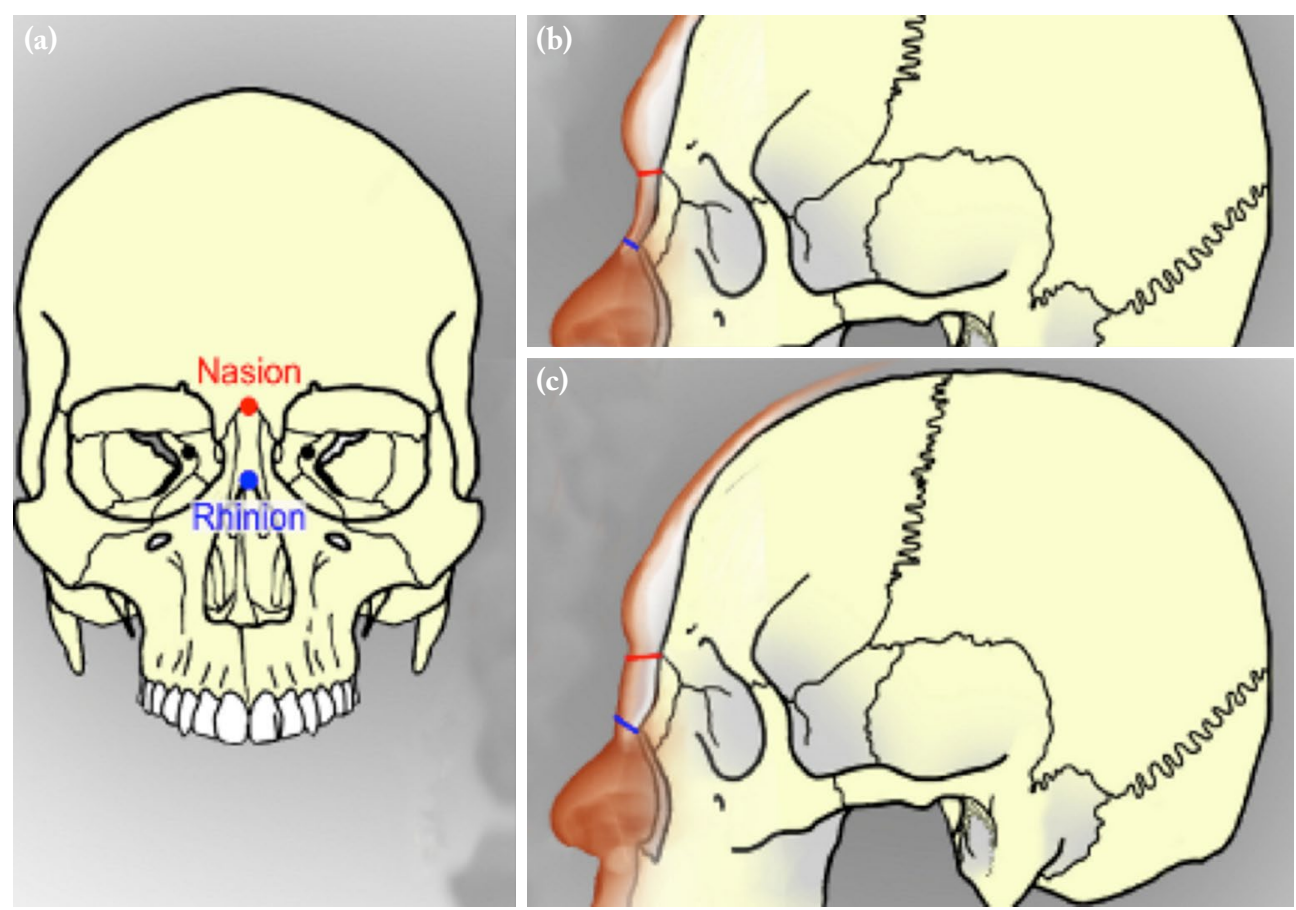

Figure 2. (a) Rhinion and nasion points. (b) Preoperative distance between periosteum and dermis. (c) Postoperative distance between periosteum and dermis. 

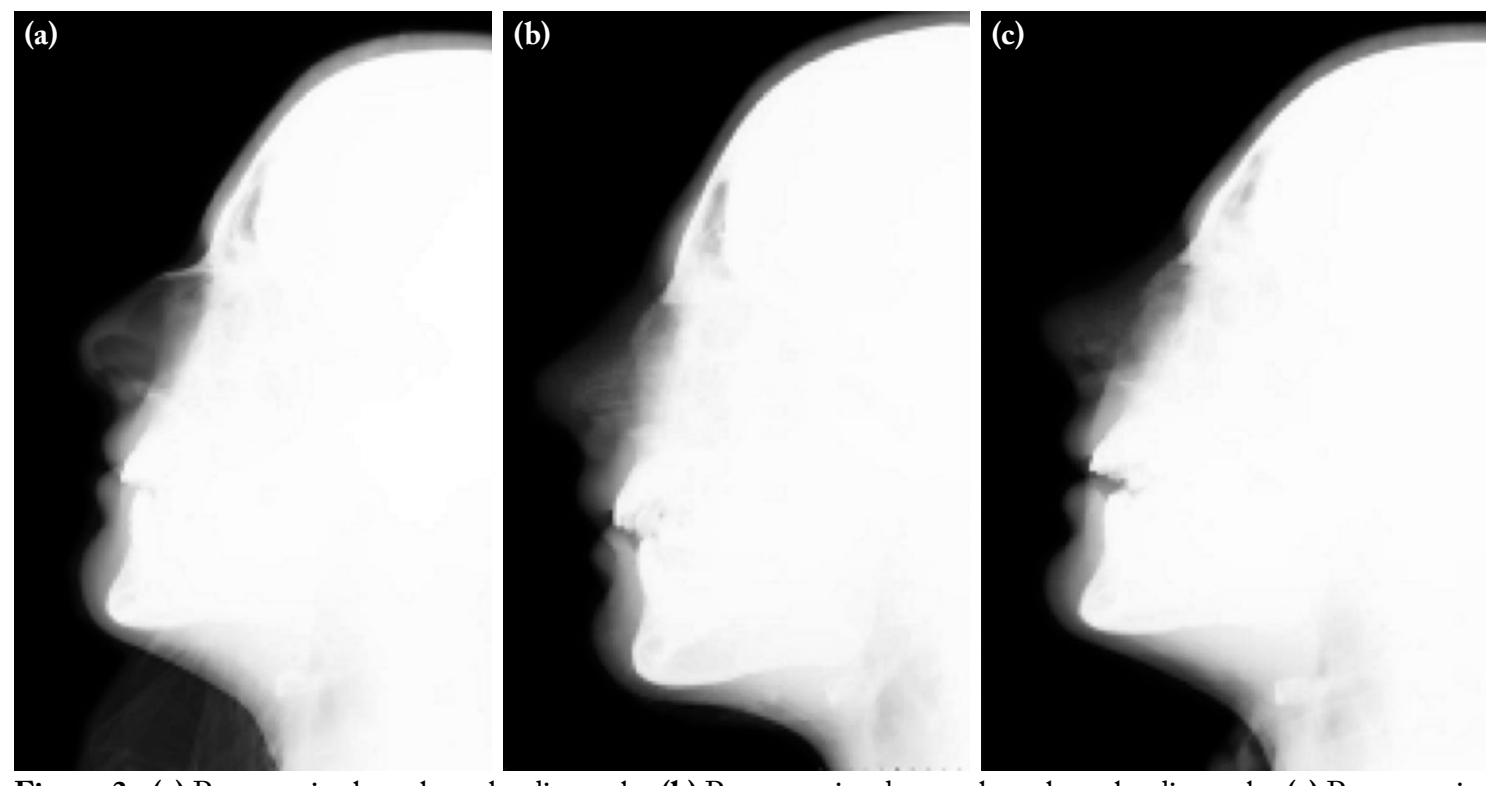

Figure 3. (a) Preoperative lateral nasal radiography. (b) Postoperative day one lateral nasal radiography. (c) Postoperative day three lateral nasal radiography.

was $100 \mathrm{~cm}$. The head was usually turned to the right, but sometimes to the left if that brought the side of interest closer to the film. The arm on the side of interest was extended parallel to the body and the other arm was bent from the elbow to support the head; the hand was placed on the table. Centralization was based on the nasal bone. The radiographic film was vertical. Each patient was told not to move after his/her position was adjusted and all collimations were made. A Konica-Minolta Regius Model 190 computerized radiography device (Konica Minolta Comp., Tokyo, Japan) was used. Postoperative edema was evaluated objectively on days one, three, and seven by the same radiology technician (Figure 3).

\section{Statistical analysis}

All statistical analyses were performed using the IBM SPSS version 20.0 software (IBM Corp., Armonk, NY, USA). Means \pm standard deviations were reported. The Friedman or Wilcoxon test was used to compare significance levels within groups. The Kruskal-Wallis or Mann-Whitney $U$ test was employed to compare significance levels between groups. If significant differences between more than two groups were evident, a post hoc test was used to identify the groups that differed. A $p$ value $<0.05$ was considered to reflect statistical significance.

\section{RESULTS}

Descriptive statistics of the groups are depicted in Table 1 . The edema scores of group 1 who underwent conventional osteotomy preoperatively and on postoperative days one, three, and seven were $2.27 \mathrm{~mm}, 6.66 \mathrm{~mm}, 5.57 \mathrm{~mm}$, and $4.68 \mathrm{~mm}$, respectively. The edema scores of group 2 who underwent conventional osteotomy and anti-inflammatory treatment preoperatively and on postoperative days one, three, and seven were $2.09 \mathrm{~mm}, 6.07 \mathrm{~mm}, 5.09 \mathrm{~mm}$, and $4.48 \mathrm{~mm}$, respectively. The edema scores of group 3 who underwent osteotomy with piezoelectric device preoperatively and on postoperative days one, three, and seven were $2.32 \mathrm{~mm}, 4.54 \mathrm{~mm}, 3.76 \mathrm{~mm}$, and $3.16 \mathrm{~mm}$, respectively. The edema scores of group 4 who underwent osteotomy with piezoelectric device and anti-inflammatory treatment preoperatively and on postoperative days one, three, and seven were $2.62 \mathrm{~mm}, 4.38 \mathrm{~mm}, 3.56 \mathrm{~mm}$, and $2.92 \mathrm{~mm}$, respectively.

Table 2 compares the pre- and postoperative edema scores; all postoperative scores were significantly higher than the preoperative scores (all $\mathrm{p}<0.001$ ).

The pre- and postoperative days one, three, and seven scores are compared in Table 3. The preoperative scores did not differ significantly among the groups $(p=0.124)$, while the postoperative scores did on all three days (all $\mathrm{p}<0.001)$. Post hoc testing revealed that groups 1 and 2 significantly differed only on day one. Groups 3 and 4 never significantly differed. Groups 1 and 3,2 and 3 , 1 and 4 , and 2 and 4 significantly differed on all 
Table 1

Descriptive statistics

\begin{tabular}{|lll|}
\hline & $\mathrm{n}$ & $\mathrm{Mean} \pm \mathrm{SD}$ \\
\hline Group 1 (Conventional osteotomy) & 22 & \\
Preoperative & 22 & $6.7 \pm 0.6$ \\
Postoperative day 1 & 22 & $5.6 \pm 0.9$ \\
Postoperative day 3 & 22 & $4.7 \pm 0.9$ \\
Postoperative day 7 & & \\
Group 2 (Conventional osteotomy and an anti-inflammatory agent) & 23 & $2.1 \pm 0.8$ \\
Preoperative & 23 & $6.1 \pm 1.1$ \\
Postoperative day 1 & 23 & $5.1 \pm 1.1$ \\
Postoperative day 3 & 23 & $4.5 \pm 1.0$ \\
Postoperative day 7 & & \\
Group 3 (Piezosurgery) & 25 & $2.3 \pm 1.0$ \\
Preoperative & 25 & $4.5 \pm 1.1$ \\
Postoperative day 1 & 25 \\
Postoperative day 3 & 25 & $3.8 \pm 1.1$ \\
Postoperative day 7 & 25 & $3.2 \pm 1.0$ \\
Group 4 (Piezosurgery and an anti-inflammatory agent) & & \\
Preoperative & & \\
Postoperative day 1 & 26 & $2.6 \pm 0.9$ \\
Postoperative day 3 & 26 & $4.4 \pm 1.1$ \\
Postoperative day 7 & 26 & $3.6 \pm 1.0$ \\
\hline SD: Standard deviation. & 26 & $2.9 \pm 0.9$ \\
\hline
\end{tabular}

Table 2

Comparisons of pre- and postoperative edema scores

\begin{tabular}{|c|c|c|c|}
\hline & $\mathrm{n}$ & Mean \pm SD & $p$ \\
\hline Group 1 & & & $<0.001^{*}$ \\
\hline Preoperative & 22 & $2.3 \pm 0.6$ & \\
\hline Postoperative mean of day 1,3 , and 7 scores & 22 & $5.6 \pm 0.9$ & \\
\hline Group 2 & & & $<0.001^{*}$ \\
\hline Preoperative & 23 & $2.1 \pm 0.8$ & \\
\hline Postoperative mean of day 1,3 , and 7 scores & 23 & $5.2 \pm 1.0$ & \\
\hline Group 3 & & & $<0.001^{*}$ \\
\hline Preoperative & 25 & $2.3 \pm 1.0$ & \\
\hline Postoperative mean of day 1,3 , and 7 scores & 25 & $3.8 \pm 1.0$ & \\
\hline Group 4 & & & $<0.001^{*}$ \\
\hline Preoperative & 26 & $2.6 \pm 0.9$ & \\
\hline Postoperative mean of day 1,3 , and 7 scores & 26 & $3.6 \pm 1.0$ & \\
\hline
\end{tabular}

three postoperative days. Thus, edema scores were significantly lower in the groups that underwent piezosurgery rather than conventional osteotomy. Anti-inflammatory therapy had only a short-term effect (one day) after conventional osteotomy and no effect after piezosurgery.

\section{DISCUSSION}

Rhinoplasty is a cosmetic surgery; however, early postoperative edema compromises both aesthetics and nasofascial functions. This leads to dissatisfaction among patients and surgeons. Various surgical methods 


\begin{tabular}{|c|c|c|c|}
\hline \multicolumn{4}{|c|}{$\begin{array}{c}\text { Table } 3 \\
\text { Edema scores preoperatively and on postoperative days one, three, and seven }\end{array}$} \\
\hline & $\mathrm{n}$ & Mean \pm SD & $p$ \\
\hline Preoperative & & & 0.124 \\
\hline Group 1 & 22 & $2.3 \pm 0.6$ & \\
\hline Group 2 & 23 & $2.1 \pm 0.8$ & \\
\hline Group 3 & 25 & $2.3 \pm 1.0$ & \\
\hline Group 4 & 26 & $2.6 \pm 0.9$ & \\
\hline Total & 96 & $2.3 \pm 0.8$ & \\
\hline Postoperative day 1 & & & $<0.001^{*}$ \\
\hline Group 1 & 22 & $6.7 \pm 1.2$ & $(1-2,1-3,1-4,2-3,2-4)$ \\
\hline Group 2 & 23 & $6.1 \pm 1.1$ & \\
\hline Group 3 & 25 & $4.5 \pm 1.1$ & \\
\hline Group 4 & 26 & $4.4 \pm 1.1$ & \\
\hline Total & 96 & $5.4 \pm 1.5$ & \\
\hline Postoperative day 3 & & & $<0.001^{*}$ \\
\hline Group 1 & 22 & $5.6 \pm 0.9$ & $(1-3,1-4,2-3,2-4)$ \\
\hline Group 2 & 23 & $5.1 \pm 1.1$ & \\
\hline Group 3 & 25 & $3.8 \pm 1.1$ & \\
\hline Group 4 & 26 & $3.6 \pm 1.0$ & \\
\hline Total & 96 & $4.4 \pm 1.3$ & \\
\hline Postoperative day 7 & & & $<0.001^{*}$ \\
\hline Group 1 & 22 & $4.7 \pm 0.9$ & $(1-3,1-4,2-3,2-4)$ \\
\hline Group 2 & 23 & $4.5 \pm 1.0$ & \\
\hline Group 3 & 25 & $3.2 \pm 1.0$ & \\
\hline Group 4 & 26 & $2.9 \pm 0.9$ & \\
\hline Total & 96 & $3.8 \pm 1.2$ & \\
\hline
\end{tabular}

including piezosurgery and various agents including steroids have been used in efforts to reduce edema after rhinoplasty. We found that nasal edema measured via lateral nasal radiography was significantly less after piezoelectric than conventional osteotomy. Anti-inflammatory treatment of patients undergoing conventional osteotomy was of benefit on day one postoperatively but not later; such treatment had no effect in patients undergoing piezosurgery.

As rhinoplastic piezosugery has become more common in recent years, many authors have explored whether this technique reduces postoperative edema and ecchymosis. Three relevant meta-analyses and reviews have appeared. Kim et al. ${ }^{[7]}$ reported that the extent of intraoperative mucosal damage was significantly less in a test than a control group while operation times were significantly longer in the test group. Eyelid edema and ecchymosis, and nasal edema and ecchymosis on postoperative day three were significantly reduced in the test group. Mirza et al. ${ }^{[3]}$ reported that piezosurgery was associated with significantly less edema and ecchymosis on postoperative days three, five, and seven. Moreover, Wähmann et al. ${ }^{[11]}$ found that piezosurgery caused significantly less edema and ecchymosis than conventional osteotomy in five studies, but one study found no significant difference. We used lateral nasal radiography to show that piezoelectric surgery was associated with less edema than conventional surgery.

Steroids and other anti-inflammatory agents have been extensively used in efforts to reduce postoperative edema in patients undergoing rhinoplasty. Some studies have found that steroids are beneficial; others have not. In a study by Kara and Gökalan, ${ }^{[8]}$ single-dose dexamethasone reduced upper and lower eyelid edema and ecchymosis over the first two days, but not later. In a meta-analysis of 336 patients (eight studies), Coroneos et al. $^{[12]}$ found that a single dose of perioperative corticosteroid reduced both edema and ecchymosis on day one but not day seven postoperatively. Hwang et al. ${ }^{[13]}$ reported that multiple-dose steroids were more 
effective than single-dose steroids. Kargi et al. ${ }^{[14]}$ found that three steroid doses were better than one. We found that preoperative single-dose dexamethasone reduced edema on day one, but not days three and seven, in patients who underwent conventional osteotomy; the treatment had no effect at any time after piezosurgery. No prior study has compared piezosurgery with and without an anti-inflammatory therapy. We found no significant differences in edema scores on days one, three, and seven after piezosurgery with and without anti-inflammatory therapy. This may be because piezosurgery per se effectively reduces postoperative edema.

Subjective methods have often been used to measure edema after rhinoplastic piezosurgery and conventional surgery. However, in a study that investigated the effects of steroid therapy on edema, Berinstein et al. ${ }^{[15]}$ used magnetic resonance imaging (MRI) to objectively measure post-surgery edema. Magnetic resonance imaging was simple and accurate, but expensive. Thus, we used lateral nasal radiography to measure edema of the nasal dorsum; this is novel, easy, practical, and inexpensive, but less accurate than MRI. Eyelid edema is usually assessed subjectively. As Berinstein et al. ${ }^{[15]}$ stated, objective and subjective data may differ. This may explain why we found no long-term effects of anti-inflammatory drugs on edema scores, unlike other studies.

A limitation of our work was that the number of patients in each group was low (average 25). In addition, we did not compare ecchymosis status, operation times, or complication rates among the groups.

In conclusion, piezosurgery effectively prevents edema after rhinoplastic osteotomy. Single-dose anti-inflammatory therapy given just before rhinoplasty was effective early after conventional osteotomy, but not later, and not at all after piezosurgery. Lateral nasal radiography is accurate, practical, easily accessible, inexpensive, and objective when used to derive edema scores. However, more research on larger sample sizes is required.

\section{Acknowledgments}

The author would like to thank the chief physician of Bahat Hospital, Dr. Hamza Bahat, and Dr. Ali Emektar from the Department of Radiology well as Yeni Yüzy1l University, and the Department of Ear Nose and Throat of Istanbul University.

\section{Declaration of conflicting interests}

The author declared no conflicts of interest with respect to the authorship and/or publication of this article.

\section{Funding}

The author received no financial support for the research and/or authorship of this article.

\section{REFERENCES}

1. Gerbault O, Daniel RK, Kosins AM. The Role of Piezoelectric Instrumentation in Rhinoplasty Surgery. Aesthet Surg J 2016;36:21-34.

2. Demirbilek N, Evren C. Is Piezoelectric Surgery Really Harmless to Soft Tissue? J Craniofac Surg 2019;30:1966-9.

3. Mirza AA, Alandejani TA, Al-Sayed AA. Piezosurgery versus conventional osteotomy in rhinoplasty: A systematic review and meta-analysis. Laryngoscope 2019. [Epub ahead of print]

4. Robiony M, Polini F. Piezosurgery: a safe method to perform osteotomies in young children affected by hemifacial microsomia. J Craniofac Surg 2010;21:1813-5.

5. Pavlíková G, Foltán R, Horká M, Hanzelka T, Borunská $\mathrm{H}$, Sedý J. Piezosurgery in oral and maxillofacial surgery. Int J Oral Maxillofac Surg 2011;40:451-7.

6. Robiony M, Toro C, Costa F, Sembronio S, Polini F, Politi M. Piezosurgery: a new method for osteotomies in rhinoplasty. J Craniofac Surg 2007;18:1098-100.

7. Kim DH, Kang H, Jin HJ, Hwang SH. Effect of piezoelectric osteotomy on postoperative oedema and ecchymosis after rhinoplasty. Clin Otolaryngol 2019;44:968-74.

8. Kara CO, Gökalan I. Effects of single-dose steroid usage on edema, ecchymosis, and intraoperative bleeding in rhinoplasty. Plast Reconstr Surg 1999;104:2213-8.

9. Yücel OT. Which type of osteotomy for edema and ecchymosis: external or internal? Ann Plast Surg 2005;55:587-90.

10. Tirelli G, Tofanelli M, Bullo F, Bianchi M, Robiony M. External osteotomy in rhinoplasty: Piezosurgery vs osteotome. Am J Otolaryngol 2015;36:666-71.

11. Wähmann M, Riedel F, Kovacevic M, Hopf A, Albers AE. Vergleich von piezoelektrisch assistierter und konventioneller Osteotomie bei der Rhinoplastik : Ein systematisches Review [Comparison of piezoelectric and conventional osteotomy in rhinoplasty: A systematic review]. HNO 2019;67:98-109.

12. Coroneos CJ, Voineskos SH, Cook DJ, Farrokyar F, Thoma A. Perioperative Corticosteroids Reduce ShortTerm Edema and Ecchymosis in Rhinoplasty: A MetaAnalysis. Aesthet Surg J 2016;36:136-46.

13. Hwang SH, Lee JH, Kim BG, Kim SW, Kang JM. The efficacy of steroids for edema and ecchymosis after rhinoplasty: a meta-analysis. Laryngoscope 2015;125:92-8.

14. Kargi E, Hoşnuter M, Babucçu O, Altunkaya $H$, Altinyazar C. Effect of steroids on edema, ecchymosis, and intraoperative bleeding in rhinoplasty. Ann Plast Surg 2003;51:570-4.

15. Berinstein TH, Bane SM, Cupp CL, DeMarco JK, Hunsaker DH. Steroid use in rhinoplasty: an objective assessment of postoperative edema. Ear Nose Throat J 1998;77:40-3. 